\title{
Ukrzyżowany czy Zmartwychwstały? Przemyślenia biblijno-liturgiczne o roli i miejscu krzyża w prezbiterium
}

W kontaktach z protestantami można się spotkać z pytaniem, dlaczego w świątyniach katolickich widzi się tak często wizerunek Chrystusa na krzyżu. Przecież Chrystus zmartwychwstał, On żyje, a więc krzyż powinien być pusty. Co prawda nie byłoby zmartwychwstania bez ukrzyżowania, jednakże - jak podkreślają protestanci - ukrzyżowanie nie było końcem życia Jezusa, lecz zwycięstwem uwidocznionym ostatecznie przez Jego zmartwychwstanie. Z tego powodu w większości protestanckich świątyń można zobaczyć pusty krzyż bez wizerunku Chrystusa ukrzyżowanego. Protestanci dodają nawet, że dobrym komentarzem do obecności pustego krzyża w świątyni są słowa św. Pawła: „Jeśli Chrystus nie zmartwychwstał, daremne jest nasze nauczanie, próżna jest także wasza wiara. [...] Skoro umarli nie zmartwychwstają, przeciwko Bogu świadczyliśmy, że z martwych wskrzesił Chrystusa. Skoro umarli nie zmartwychwstają, to i Chrystus nie zmartwychwstał. A jeżeli Chrystus nie zmartwychwstał, daremna jest wasza wiara i aż dotąd pozostajecie w swoich grzechach. [...] Tymczasem jednak Chrystus zmartwychwstał jako pierwszy spośród tych, co pomarli" (1 Kor 15, 14-20). W związku z tym - twierdzą protestanci - pusty krzyż w świątyni jest najwłaściwszym znakiem zmartwychwstania Chrystusa.

Nie ma wątpliwości, że powyższe słowa św. Pawła są jednoznaczne: bez zmartwychwstania Chrystusa nasza wiara i nadzieja tracą sens i wówczas chrześcijaństwo przekształca się w nostalgiczną opowieść. Jak więc odpowiedzieć na protestancki zarzut, że katolicy zatrzymali 
się ponoć w swoich świątyniach na śmierci Jezusa, a zapomnieli o Jego zmartwychwstaniu, skoro w katolickich kościołach Pan Jezus nad al wisi na krzyżu?

Ta kwestia staje się dla nas jeszcze bardziej istotna, ponieważ w ostatnich latach w katolickich świątyniach można się czasami spotkać ze zjawiskiem, które w pewnym sensie wiąże się z powyższym zarzutem lub problemem przedstawionym przez protestantów. Bywa bowiem, że w kościołach i kaplicach katolickich wizerunek Chrystusa ukrzyżowanego jest zastąpiony wizerunkiem Chrystusa zmartwychwstałego. W niektórych przypadkach jest to zmartwychwstały Chrystus na krzyżu, a w innych jest to jedynie figura zmartwychwstałego z wyciągniętymi rękami przypominającymi ukrzyżowanie. Wizerunki tego rodzaju są motywowane teologicznym spostrzeżeniem, że śmierći zmartwychwstanie Chrystusa to jedna rzeczywistość paschalna, której nie da się rozdzielić, a najlepszym artystycznym jej ukazaniem jest wizerunek Chrystusa zmartwychwstałego w chwale, triumfującego z krzyża lub bez niego ${ }^{1}$. Tłumaczy się też, że w ten sposób bardziej wymownie można pokazać współczesnemu człowiekowi, iż krzyż nie jest porażką, lecz zwycięstwem.

Zapewne to teologiczne spostrzeżenie jest trafne i wiąże się ze wspomnianymi wcześniej słowami św. Pawła (1 Kor 15, 14-20). Trzeba jednak pamiętać, że w Kościele katolickim wszystko, co dotyczy liturgii i świątyni, jest uregulowane przepisami. Ogólne wprowadzenie do mszału rzymskiego podaje, że „na ołtarzu lub w jego pobliżu ma się znajdować krzyż z wizerunkiem Chrystusa ukrzyżowanego"- „Item super altare vel prope ipsum habeatur crux, cum effigie Christi crucifixi" (117). Kolejne zdanie w polskim tłumaczeniu brzmi następująco: „Świeczniki i krzyż można też wnieść w procesji na wejście”. o dziwo, nie jest to pełne tłumaczenie zdania, które w łacińskim oryginale brzmi: „Candelabra autem et crux effigie Christi crucifixi or $\mathrm{n}$ a t a in processione ad introitum afferri possunt" (117). Polskie tłumaczenie opuszcza słowa „z wizerunkiem Chrystusa ukrzyżowanego”.

Dalej Ogólne wprowadzenie... wskazuje, że „przyniesiony w procesji krzyż z wizerunkiem Chrystusa ukrzyżowanego można ustawić obok ołtarza, aby pełnił funkcję krzyża ołtarzowego, który

${ }^{1}$ Na temat jedności krzyża i zmartwychwstania jako Pascha Domini por. W. Kasper, Jezus Chrystus, Warszawa 1983, s. 151. 
winien byćtylkojeden” (122) - „Crux effigie Christi crucifixi or $n$ a ta et in processione delata, iuxta altare erigi potest ut fiat crux altaris, quae una tantum esse debet, secus reponatur". W innym odniesieniu do krzyża w Ogólnym wprowadzeniu... czytamy, że „, na ołtarzu lub obok niego należy umieścić krzyż z wi zeru nki e m Chrystusa ukrzyżowa ne go dobrze widoczny dla zgromadzonych wiernych. Wypada pozostawić ten krzyż przy ołtarzu także poza czasem sprawowania liturgii, aby przypominał wiernym zbawczą mękę Pana” - „Item super altare vel prope ipsum crux, cum effigie Christi crucifixi, habeatur, quae a populo congregato bene conspiciatur. Expedit ut huiusmodi crux, ad salutiferam Domini passionem in mentem fidelium revocandam, etiamextra celebrationes liturgicas prope altare permaneat" (308). W tym miejscu znamienne są słowa: ,aby przypominał wiernym zbawczą mękę Pana". Jest to wyraźne odniesienie do istoty ofiary Chrystusa na krzyżu, która zostaje uobecniona w każdej mszy świętej.

Wczytując się w powyższe liturgiczne przepisy, ktoś mógłby zwrócić uwagę, że dotyczą one tylko krzyża ołtarzowego. Niemniej jednak tu właśnie pojawia się problem. Zdarza się bowiem, że w prezbiteriach nie ma ani krzyża ołtarzowego, ani krzyża procesjonalnego ${ }^{2}$. Nie chodzi o to, że nie można umieścić $\mathrm{w}$ prezbiterium dodatkowego wizerunku krzyża z Chrystusem zmartwychwstałym, czy to w postaci ikony (nawet na ścianie), czy w innej formie. Chodzi o to, że w prezbiterium powinien być wyraźnie obecny - przede wszystkim - wizerunek Chrystusa ukrzyżowanego ${ }^{3}$. Zgodnie z przepisami Ogólnego wprowadzenia... należy umieścić krzyż, który ma przypomnieć wiernym zbawczą mękę Pana.

Z czego więc wynikają te liturgiczne przepisy dotyczące krzyża przypominającego ludowi Bożemu mękę Pańską? Jakie jest ich uzasadnienie? Okazuje się, że uzasadnienie tych przepisów jest biblijne. Często przywoływany przez protestantów wcześniej wspomniany tekst 1 Kor 15 , 14-20 należy zrozumieć w szerszym kontekście słów św. Pawła w innych miejscach. Mianowicie: „My głosimy Chrystusa ukrzyżowanego, który jest zgorszeniem dla Żydów, a głupstwem dla pogan, dla tych zaś, którzy są powołani, tak spośród Żydów, jak i spośród Greków, Chrystusem, mocą

\footnotetext{
${ }^{2}$ Jest to zjawisko, z którym można się spotkać zwłaszcza w kaplicach.

${ }^{3}$ Por. J. Ratzinger, Duch liturgii, Poznań 2002, s. 77.
} 
Bożą i mądrością Bożą” (1 Kor 1, 23-24); „Postanowiłem bowiem, będąc wśród was, nie znać niczego więcej, jak tylko Jezusa Chrystusa, i to ukrzyżowanego” (1 Kor 2, 2); „Co do mnie, nie daj Boże, bym się miał chlubić z czego innego, jak tylko z krzyża Pana naszego Jezusa Chrystusa, dzięki któremu świat stał się ukrzyżowany dla mnie, a ja dla świata" (Ga 6,14).

Zwróćmy uwagę, że słowa św. Pawła odnoszą się do głoszenia i poznania Chrystusa ukrzyżowanego oraz do chluby z Jego krzyża. To właśnie w tym kontekście trzeba dodać, że istotą mszy świętej jest ofiara Chrystusa na krzyżu ${ }^{4}$. Krzyż bez Chrystusa staje się abstrakcją, bo samo ukrzyżowanie z punktu widzenia historycznego nie jest czymś wyjątkowym - wiele osób poniosło śmierć na krzyżu ${ }^{5}$ To natomiast, że Bóg wybrał tę haniebną formę śmierci dla swojego Syna, który z kolei dobrowolnie przyjął ten rodzaj śmierci, stanowi dla nas najpiękniejsze świadectwo miłości Boga do człowieka ${ }^{6}$. Bóg bowiem nie tylko przyszedł na świat, nie tylko umarł, ale oddał za nas życie. Zatem wizerunek Chrystusa ukrzyżowanego w prezbiterium, zwłaszcza tam, gdzie najświętsza ofiara Golgoty zostaje uobecniona dzień w dzień, uświadamia każdemu, że nie można oskarżyć Boga, iż nie rozumie ludzi w ich codziennym cierpieniu. Bóg zrozumiał człowieka do końca, bo do końca go umiłował - aż do krzyża. Poza tym w najświętszej ofierze mszy świętej Bóg daje nam siłę, abyśmy mogli odpowiedzieć na każde wezwanie i podjąć wszelkie zmaganie dla Jezusa, bo żadne cierpienie nie jest czymś bezsensownym dopóty, dopóki jest ono rozważane w świetle krzyża, na którym wisi Chrystus. Św. Paweł podkreśla: „Razem z Chrystusem zostałem przybity do krzyża. Teraz zaś już nie ja żyję, lecz żyje we mnie Chrystus. Choć nadal prowadzę życie w ciele, jednak obecne życie moje jest życiem wiary w Syna Bożego, który umiłował mnie i samego siebie wydał za mnie" (Ga 2, 19-20). To właśnie krzyż w świetle Eucharystii oraz Eucharystia w świetle krzyża ciągle przypominają, że wszystko, co się dzieje w naszym życiu, nie tylko można, ale trzeba rozważyć w odnie-

${ }^{4}$ Por. Jan Paweł II, list apost. Dominicae cenae, 9; J. Ratzinger, Duch liturgii, dz. cyt., s. 116.

${ }^{5}$ Por. M. Hengel, Crucifixion in the Ancient World, and the Folly of the Message of the Cross, London 1986, s. 22-63, 86-87.

${ }^{6}$ Por. H. U. von Balthasar, Teologia misterium paschalnego, Kraków 2001, s. 138; J. Ratzinger, H. U. von Balthasar, Mary: The Church at the Source, San Francisco 2005, s. 77. 
sieniu do Boga, który wyprowadza dobro nawet z największego zła ${ }^{7}$. Ta prawda nie zostaje w pełni oddana, jeżeli w prezbiterium miałby się znajdować jedynie wizerunek pustego krzyża lub wizerunek Chrystusa w chwale bez odniesienia do Jego męki - na krzyżu lub bez krzyża. Syn Boży nie szedł na skróty - do chwały zmartwychwstania doszedł przez mękę, a brak odniesienia do tej męki sprawia wrażenie, że nie do końca solidaryzował się z człowiekiem.

Św. Edyta Stein stwierdziła, że „nieustannie trwająca ofiara Chrystusa na krzyżu, na Mszy świętej oraz w wieczystej chwale nieba może być rozumiana jako jeden akt wielkiego dziękczynienia, czyli jako Eucharystia". Inaczej mówiąc, Chrystus na krzyżu stanowi stały punkt odniesienia dla tego wszystkiego, co dzieje się na ołtarzu Pańskim. W tym świetle należy też zrozumieć zarządzenie Ojca świętego Benedykta XVI, aby na wszystkich papieskich mszach świętych znajdował się na ołtarzu krzyż z wizerunkiem Chrystusa ukrzyżowanego' ${ }^{9}$. Taki ołtarzowy krzyż jest ważny nie tylko dla ludu Bożego, który bierze udział w liturgii, ale również dla celebransa. To zwłaszcza kapłan sprawujący najświętszą ofiarę ma pamiętać, czym - na pierwszym miejscu - jest msza święta: najświętszą ofiarą złożoną w Wielki Piątek jako dzieło naszego odkupienia. Godne podkreślenia jest to, że już Jan Paweł II zwrócił uwage na niepokojący fenomen polegający na tym, iż „czasami spotyka się bardzo ograniczone rozumienie tajemnicy Eucharystii. Ogołocona z jej wymiaru ofiarniczego, jest przeżywana w sposób nie wykraczający poza sens i znaczenie zwykłego braterskiego spotkania"10. Jest to niewątpliwie wynik wpływu protestantyzmu na zachodzie. Istnieje niebezpieczeństwo, że wpływ ten wkraść się może nawet do Kościoła katolickiego. Dlatego też krzyż z wizerunkiem Chrystusa ukrzyżowanego (szczególnie na oł-

${ }^{7}$ Por. K. Rahner, Spiritual writings, ed. by P. Endean, Maryknoll 2004, s. 75.

${ }^{8}$ E. Stein, Essential Writings, selected with an introduction by J. Sullivan, Maryknoll 2002, s. 46.

${ }^{9}$ Biuro Ceremonii Papieskich wydało uzasadniający komunikat w tej sprawie pt. The Crucifix at the Center of the Altar, www.vatican.va/news_services/liturgy/details/ ns_lit_doc_20091117_crocifisso_en.html [5.10.2010]. Długo przed wyborem na Stolicę Piotrową kard. Ratzinger nazwał priorytetem przywrócenie właściwego znaczenia krzyża w tradycji chrześcijańskiej oraz liturgii; por. J. Ratzinger, Święto wiary. O teologii Mszy świętej, Kraków 2006, s. 138.

${ }^{10}$ Jan Paweł II, enc. Ecclesia de Eucharistia, 10. 
tarzu, na którym jest sprawowana Eucharystia) ma ciągle przypominać, że msza święta jest więcej niż spotkaniem, na którym lud Boży gromadzi się, aby uwielbiać Boga. To prawda, że każda Eucharystia ma wymiar wspólnotowy na poziomie horyzontalnym, czyli międzyludzkim, jednak wymiar ten nie jest istotą Eucharystii. Msza święta to przede wszystkim spotkanie Boga z człowiekiem i tak też należy ją przeżywać, zachowując liturgiczne sacrum, kierujące nasz umysł ku liturgii niebiańskiej.

Niestety, to spotkanie Boga z człowiekiem podczas sprawowania Eucharystii nie zawsze jest odpowiednio przeżywane przez kapłana sprawującego mszę świętą. Można się czasami spotkać z błędną praktyką polegającą na tym, że celebrans w czasie modlitwy przy ołtarzu nawiązuje kontakt wzrokowy z wiernymi. Należy zauważyć, że modlitwa mszalna jest zawsze skierowana do Boga Ojca, a nie do ludu Bożego. Kapłan, odmawiając tę modlitwę i jednocześnie nawiązując kontakt wzrokowy $\mathrm{z}$ wiernymi $\mathrm{w}$ zwyczajnej formie mszy świętej versus populum stwarza wrażenie, że nie wie, co czyni. Jest to błędna postawa z punktu widzenia liturgicznego i teologicznego ${ }^{11}$. Prowadzi ona do złych konsekwencji duszpasterskich, ponieważ w takiej sytuacji - kiedy to właśnie swoim skupieniem kapłan ma świadczyć o tajemnicy rozgrywającej się podczas najświętszej ofiary sprawowanej na ołtarzu, szczególnie w zwyczajnej formie mszy świętej - odnosi się wrażenie, że on wcale nie przeżywa tego świętego obrzędu jako spotkania z Bogiem, leczjako dialog z wiernymi. Podczas liturgii mszalnej są części wymagające bezpośredniego zwrócenia się do ludu (pozdrowienie, wprowadzenie do prefacji, błogosławieństwo itd.), ale w tych przypadkach jest jasne dla wszystkich, że liturgia przewiduje zwrócenie się kapłana do ludu, a nie do Boga ${ }^{12}$. Dlatego też, jeśli celebrans podczas modlitwy eucharystycznej, jak również podczas innych modlitw mszalnych skierowanych do Boga, modli się i jednocześnie wpatruje się w lud Boży, daje do zrozumienia, że to, co się dzieje przy ołtarzu, jest mu obce. A jeżeli to, co się dzieje przy ołtarzu, jest mu obce, to znaczy, że nie ma świadomości, iż występuje przy ołtarzu in persona Christi. W związku z tym, słowa Ojca świętego

${ }^{11}$ Por. J. Ratzinger, Święto wiary..., dz. cyt., s. 138.

${ }^{12}$ Ta jasność wynika z treści liturgicznego tekstu („Pan z wami” itd.) oraz z rubryki („Potem kapłan zwraca się do ludu i rozkładając ręce, pozdrawia go, mówiąc” itd.). 
Benedykta XVI na temat konieczności identyfikacji kapłana z jego posługą są jak najbardziej trafne ${ }^{13}$.

Papież Benedykt XVI w niedawno napisanym wprowadzeniu do zbioru wszystkich swoich dzieł podkreślił między innymi, że idea, według której kapłan ma patrzeć na wiernych, a wierni na niego podczas modlitwy była obca chrześcijaństwu od samego początku, ponieważ w trakcie odmawiania modlitw liturgicznych kapłan nigdy nie był zwrócony do ludu, a lud nigdy nie był zwrócony do kapłana. Kapłan wraz z wiernymi byli zawsze zwróceni w tę samą stronę, czyli ku Bogu. W tym kontekście Benedykt XVI, nawiązując do kwestii umiejscowienia krzyża na ołtarzu, podkreśla, że krzyż na środku ołtarza jako punkt odniesienia sprawia, iż podczas modlitwy ani kapłan nie patrzy na ludzi, ani ludzie nie patrzą na kapłana. Lud Boży i kapłan dają się prowadzić w stronę Tego, do którego wszyscy mają się modlić1 ${ }^{14}$. Wówczas kapłan i wierni nie adorują siebie nawzajem, lecz angażują się w modlitwę skierowaną do Boga, a pomocą w tym celu jest właśnie krzyż na środku ołtarza. W związku z tym słowa św. Pawła do Galatów mogą służyć jako ostrzeżenie, abyśmy nie stracili właściwego kierunku modlitwy: „O, nierozumni Galaci! Któż was urzekł, was, przed których oczami nakreślono obraz Jezusa Chrystusa ukrzyżowanego?" (Ga 3,1).

Jest jeszcze jedna kwestia, która może wzbudzić wątpliwość co do obecności krzyża i jego miejsca w prezbiterium kościoła lub kaplicy. Skoro krzyż - zwłaszcza z wizerunkiem Chrystusa ukrzyżowanego - podkreśla ofiarniczy aspekt mszy świętej, to jednak pozostaje pytanie, czy jest coś w prezbiterium, co wskazałoby na zmartwychwstanie Chrystusa? Bądź co bądź prawda o zmartwychwstaniu musi być jasno odczytana w prezbiterium, inaczej pozostalibyśmy - jak to określają protestanci - pogrążeni w smutku Wielkiego Piątku bez nadziei Wielkiej Niedzieli.

W odpowiedzi trzeba zwrócić uwagę na dwie kwestie. Pierwsza to fakt, że msza święta sama w sobie zawiera liczne odniesienia do zmartwychwstania Chrystusa. Między innymi można byłoby tu wskazać na wyznanie wiary, poszczególne prefacje mszalne, a zwłaszcza modlitwy euchary-

${ }^{13}$ Por. Benedykt XVI, List na rozpoczęcie Roku Kapłańskiego z okazji dies natalis św. proboszcza z Ars, 16 czerwca 2009.

${ }^{14}$ Por. J. Ratzinger, Gesammelte Schriften, t. 11: Theologie der Liturgie, Freiburg 2008, s. 7. Wprowadzenie Benedykta XVI do tego 16-tomowego dzieła nosi datę 29 czerwca 2008. 
styczne, gdzie w polskim mszale są cztery aklamacje po przeistoczeniu do wyboru przez celebransa, na które każda z czterech możliwych odpowiedzi ludu nawiązuje do zmartwychwstania ${ }^{15}$. Nie można pominąć faktu, że w tych czterech odpowiedziach są również zawarte odniesienia do ofiary Chrystusa na krzyżu ${ }^{16}$. Poza tymi przypadkami każda modlitwa eucharystyczna ma dodatkowe odniesienia do śmierci krzyżowej i do zmartwychwstania Chrystusa ${ }^{17}$. Te wszystkie przypadki są liturgicznym potwierdzeniem faktu, że ukazanie ukrzyżowania i męki Chrystusa „nie zasłania” Jego zmartwychwstania. $Z$ tej racji pod względem wizualnym nie można byłoby też powiedzieć, że umieszczenie krzyża z wizerunkiem Chrystusa ukrzyżowanego na ołtarzu - zwłaszcza podczas sprawowania mszy świętej - pomniejsza znaczenie zmartwychwstania Pana. W końcu tak jak wizerunek Chrystusa ukrzyżowanego nie może stonować faktu Jego zmartwychwstania, tak też krzyż na ołtarzu nie przeszkadza w sprawowaniu Eucharystii, nawet jeżeli miałby się znajdować na środku ołtarza między celebransem a ludem uczestniczącym

${ }^{15} \mathrm{~W}$ trzech przypadkach to nawiązanie do zmartwychwstania jest bezpośrednie: „Głosimy śmierć Twoją, Panie Jezu, wyznajemy Twoje zm a r t w y ch w st a n i e i oczekujemy Twego przyjścia w chwale”; „Panie, Ty nas wybawiłeś przez krzyż i z martwychwstanie swoje, Ty jesteś Zbawicielem świata”; „Chrystus umarł, Chrystus z mart w y ch ws t ał, Chrystus powróci". W jednym przypadku nawiązanie do zmartwychwstania jest pośrednie: „Ile razy ten chleb spożywamy i pijemy z tego kielicha, głosimy śmierć Twoją, Panie, oczekując Twego przyjścia w chwale”.

${ }^{16} \mathrm{~W}$ jednym $\mathrm{z}$ tych przypadków to odniesienie jest bezpośrednie: „Panie, Ty nas wybawiłeś przez krzyż i zmartwychwstanie swoje”. W pozostałych przypadkach odniesienie jest pośrednie: „Głosimy śmi e rć Twoją, Panie Jezu”; Chrystus u marł, Chrystus zmartwychwstał”; „Ile razy ten chleb spożywamy i pijemy z tego kielicha, głosimy śmi e r ć Twoją, Panie".

${ }^{17}$ „Wspominając błogosławioną mękę, z martwy chwstanie oraz chwalebne wniebowstąpienie Twojego Syna” (I modlitwa eucharystyczna); „Wspominając ś m i e r ć i zmartwy chwstanie Twojego Syna” (II modlitwa eucharystyczna); ,Wspominając, Boże, zbawczą mę kę Twojego Syna, jak również cudowne Jego zmartwy chw stanie i wniebowstąpienie” (III modlitwa eucharystyczna); „Wspominamy ś mi er ć Chrystusa i Jego zstąpienie do otchłani, wyznajemy Jego z m a rt wy ch w st a ni e" (IV modlitwa eucharystyczna); „Ty sprawiłeś, że Jezus Chrystus, Twój Syn, przez mękę i krzy ż wszedł do chwały zmartwy chwstania" (V modlitwa eucharystyczna); "Obchodząc pamiątkę śm i erci i z martw y ch w st a nia Twojego Syna" (I modlitwa eucharystyczna o tajemnicy pojednania); „Obchodząc pamiątkę ś mi er ci i z martw y chws t a n i a Twojego Syna" (II modlitwa eucharystyczna o tajemnicy pojednania). 
we mszy świętej sprawowanej w formie zwyczajnej ${ }^{18}$. Chrystus ukrzyżowany i zmartwychwstały jest jednym i tym samym Chrystusem, którego lud Boży przyjmuje w czasie Eucharystii w komunii świętej, to On staje się obecny na ołtarzu po słowach konsekracji19.

Ogólne wprowadzenie do Mszału rzymskiego przypomina, że „w zi e mskiej liturgii Kościół przeżywa przedsmak uczestnictwa w liturgii niebiańskiej sprawowanej w świętym mieście, Jeruzalem, do którego pielgrzymuje, gdzie Chrystus zasiada po prawicy Boga. Wspomina też ze czcią świętych i spodziewa się, że będzie mieć jakiś udział w ich społeczności" (318) ${ }^{20}$. Wymowne potwierdzenie tego faktu znajdujemy w piątym rozdziale Apokalipsy, gdzie św. Jan Apostoł opisuje liturgię niebiańską. Należy zauważyć, że w centrum tej

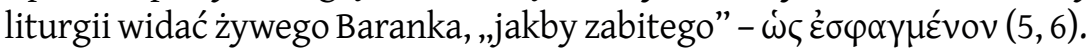
Słowa ,jakby zabitego" podkreślają, że ów Baranek to nie tylko Chrystus zmartwychwstały, lecz również Chrystus ukrzyżowany. Jeżeli chodziłoby jedynie o podkreślenie obecności Chrystusa zmartwychwstałego w centrum liturgii niebiańskiej, to wówczas słowa ,jakby zabitego" nie byłyby konieczne w tym miejscu. Te jednak odnoszą się do Chrystusa,

${ }^{18}$ Por. J. Ratzinger, Duch liturgii, dz. cyt., s. 77: „Do prawdziwie absurdalnych zjawisk ostatnich dziesięcioleci zaliczam fakt, że krzyż jest odstawiany na bok, aby nie zasłaniał kapłana. Czy krzyż przeszkadza Eucharystii? Czy kapłan jest ważniejszy od Chrystusa?"; por. J. Ratzinger, Święto wiary..., dz. cyt., s. 139. Z punktu widzenia praktycznego można korzystać z tak zwanego dwustronnego krzyża ołtarzowego, na którym z jednej i drugiej strony jest figura Chrystusa ukrzyżowanego. W ten sposób celebrans odprawiający mszę świętą w zwyczajnej formie versus populum ma przed sobą wizerunek Chrystusa ukrzyżowanego, a wierni, patrząc na ołtarz, również mają przed sobą ten sam wizerunek. Rzecz jasna, że w nadzwyczajnej formie mszy świętej wystarczy jednostronny krzyż ołtarzowy, ponieważ tu celebrans oraz lud Boży są zwróceni w tym samym kierunku.

${ }^{19} \mathrm{~W}$ tym kontekście warto zwrócić uwagę na sposób udzielania komunii świętej w nadzwyczajnej formie mszy świętej. Kapłan, podchodząc do każdej osoby klęczącej i oczekującej przyjęcia komunii świętej, czyni znak krzyża każdą konsekrowaną hostią, zanim ją poda. Ten gest potwierdza, że krzyż i zmartwychwstanie są jedną rzeczywistością paschalną. Osoba przystępująca do komunii świętej przyjmuje zmartwychwstałego Chrystusa, który żyje, mimo że oddał życie. Poza tym sam celebrans sprawujący mszę świętą w nadzwyczajnej formie, zanim spożywa Ciało Pańskie i Krew Pańską, też czyni znak krzyża: najpierw konsekrowaną hostią, a po jej spożyciu kielichem, w którym znajduje się Krew Pańska.

${ }^{20}$ Por. Jan Paweł II, enc. Ecclesia de Eucharistia, 19. 
który żyje, ale jednocześnie pojawia się podczas niebiańskiej liturgii jako Ten, który wisi na krzyżu, bo jest ,jakby zabity”. Wydaje się, że właśnie ta rzeczywistość zostaje w pełni i jasno ukazana, gdy krzyż z ukrzyżowanym Panem znajduje się na środku ołtarza, podczas gdy ten sam Chrystus - żywy Baranek ,jakby zabity" - staje się obecny na tym ołtarzu w czasie przeistoczenia.

Drugą kwestią dotyczącą podkreślenia w prezbiterium faktu Chrystusowego zmartwychwstania jest ważne spostrzeżenie, że zmartwychwstanie Jezusa jest akcentowane w katolickiej świątyni nie tylko w trakcie sprawowanej Eucharystii, lecz również poza mszą świętą dzięki obecności Chrystusa w tabernakulum. Ikona lub obraz zmartwychwstałego Pana w prezbiterium jest czymś pięknym, przypominającym nam wszystkim, że Jezus zmartwychwstał i żyje, natomiast najważniejsze miejsce w Kościele, które uświadamia osobom wchodzącym do świątyni, iż Chrystus zmartwychwstał i żyje, to właśnie tabernakulum. Tam je st zmartwychwstały Pan. Jego obecność w tabernakulum potwierdza, że śmierć została pokonana raz na zawsze, śmierć nie ma już ostatniego słowa, bo „gdzieżjest, o śmierci twoje zwycięstwo? Gdzież jest, o śmierci, twój oścień"? (1 Kor 15, 55).

W tym kontekście należy też określić jako błędne przekonanie, że tabernakulum mus i być z boku, a nie na środku prezbiterium, aby skupienie ludu Bożego było lepiej skierowane ku ołtarzowi. Według przepisów tabernakulum może być umieszczone „na środku ołtarza wielkiego lub bocznego, ale naprawdę okazałego" ${ }^{21}$. W wielu nowych kościołach i kaplicach środkowe miejsce w prezbiterium jest zarezerwowane dla głównego celebransa ${ }^{22}$. Czy taka praktyka nie wynika przypadkiem z błędnego

${ }^{21}$ Kongregacja ds. Kultu Bożego i Dyscypliny Sakramentów, instrukcja Redemptoris sacramentum, 130.

${ }^{22} \mathrm{~W}$ adhortacji apost. Sacramentum Caritatis Benedykt XVI zaznacza: „Jest zatem konieczne, by miejsce, gdzie są przechowywane Postacie Eucharystyczne, było łatwo rozpoznawalne przez każdego, kto wchodzi do kościoła [...]. W kościołach, w których nie ma kaplicy Najświętszego Sakramentu, a pozostał ołtarz główny z tabernakulum, wskazane jest, by zachować ten układ dla przechowywania i adoracji Eucharystii, unikając stawiania w tym miejscu fotela dla celebransa. W nowych kościołach dobrze jest przewidzieć kaplicę z Sanctissimum w pobliżu prezbiterium; tam gdzie to nie jest możliwe, lepsze jest usytuowanie tabernakulum w prezbiterium, w miejscu odpowiednio wyniesionym, w pośrodku przestrzeni absydalnej, lub w innym miejscu, skąd będzie 
myślenia, że kapłan jest ważniejszy od Chrystusa podczas celebracji najświętszej ofiary? Co prawda Chrystus jest obecny w osobie celebransa, ale nie takjak w Najświętszym Sakramencie ${ }^{23}$. W związku z tym w przypadku mszy świętej celebrowanej w formie zwyczajnej versus populum po raz kolejny widać słuszność spostrzeżeń papieża Benedykta XVI na temat umieszczenia krzyża z Chrystusem ukrzyżowanym na środku ołtarza, między celebransem a ludem Bożym. W ten sposób krzyż z Chrystusem ukrzyżowanym staje się dla wszystkich jasnym punktem odniesienia podczas Eucharystii (jak również poza jej sprawowaniem).

Ostatecznie, widoczny krzyż z wizerunkiem Chrystusa ukrzyżowanego w prezbiterium - zwłaszcza na ołtarzu - stanowi też wymowne przypomnienie o miejscu i roli krzyża w naszym życiu. Skoro Eucharystia sprawowana na ołtarzu jest źródłem i szczytem naszego życia chrześcijańskiego, to wówczas krzyż jako obraz Bożej miłości pomaga nam zrozumieć, że od krzyża nie wolno uciekać ${ }^{24}$. W dzisiejszych czasach krzyż jest ciągle lekceważony i odrzucany. Poza tym sama idea ofiary i cierpienia jest dla wielu ludzi czymś odpychającym i nawet przerażającym. W związku z tym naszym obowiązkiem jest nie ulegać tej mentalności i ciągle wracać do przestrogi, którą św. Paweł skierował do Galatów: „O nierozumni Galaci! Któż was urzekł, was, przed których oczami nakreślono obraz Jezusa Chrystusa ukrzyżowanego?" (Ga 3,1). Zapewne pamięć o Chrystusie ukrzyżowanym miała chronić Galatów przed pójściem za błędnym nauczaniem. Tym bardziej ucieczka przed krzyżem jest nie tylko bezsensowna, lecz nawet niebezpieczna.

„Natura ofiarnicza tajemnicy Eucharystii nie może być [...] pojmowana jako coś oddzielnego, niezwiązanego z krzyżem lub też odnoszącego się jedynie pośrednio do ofiary na Kalwarii" ${ }^{25}$. Krzyż z wizerunkiem Chrystusa ukrzyżowanego przypominający mękę Pańską - ogólnie w prezbiterium, a szczególnie na środku ołtarza - jest jasnym i potrzebnym znakiem pomagającym nam zrozumieć, że ofiarnicza miłość Chrystusa wkroczyła

równie dobrze widoczne. Takie rozwiązania przyczyniają się do uszanowania godności tabernakulum" (69).

${ }^{23}$ Por. Sobór Watykański II, konst. Sacrosanctum Concilium, 7; Katechizm Kościoła katolickiego, 1088, 1374, 1413.

${ }^{24}$ Por. J. Escrivá, Różaniec święty. Droga krzyżowa, Ząbki 2002, s. 155.

${ }^{25}$ Jan Paweł II, enc. Ecclesia de Eucharistia, 12. 
i znajduje się w centrum naszej codzienności. Nasze życie i nasza modlitwa są podjęte przez Chrystusa, aby je uświęcić i uczynić miłymi Bogu Ojcu. Tak też w każdej chwili spełniają się słowa: „A Ja, gdy zostanę nad ziemię wywyższony, przyciągnę wszystkich do siebie" (J 12,32). Niech więc wizerunek Chrystusa na krzyżu będzie wyraźnie obecny przed naszymi oczami, aby nasza wiara nigdy nie stała się abstrakcją, a nasza nadzieja nigdy nie straciła swej świeżości. My, słudzy Pana w kapłaństwie, powołani do sprawowania najświętszej ofiary każdego dnia, miejmy przed sobą Chrystusa umęczonego na krzyżu, abyśmy nie zapomnieli, co tak naprawdę czynimy przy ołtarzu. Powtarzając słowa Pana, konsekrując hostię i wino, róbmy to w świetle krzyża, nie tylko dla naszego duchowego dobra, ale również dla duchowego dobra ludu Bożego, który chce widzieć kapłanów identyfikujących się ze swoją posługą.

Kalisz

KS. JACEK STEFAŃSKI

\section{Słowa kluczowe}

Krzyż, krucyfiks, zmartwychwstanie, prezbiterium, ołtarz, tabernakulum, msza święta, Eucharystia, przepisy, liturgia

\section{Summary}

Crucified or Risen? Biblical and liturgical reflections on the role and place of the Cross in the Sanctuary

The present article looks at the place and purpose of the Cross in the Roman Catholic Sanctuary. Liturgical regulations concerning this matter have their basis in Sacred Scripture. A Cross with an image of the crucified Lord on the altar is a reminder, that the essence of the Eucharist is the holy Sacrifice of Christ on Golgotha. The Crucifix is also a reference point which helps us deepen our spiritual participation in the Mass. For this reason, placing the cross in the middle of the altar seems to be a meaningful way to emphasize the sacrificial nature of the Eucharist. Christ present in the tabernacle and the image of the crucified Lord on the Cross together point to the paschal unity of the Passion and Resurrection of Christ, as it is seen in the Mass.

\section{Keywords}

Cross, crucifix, resurrection, sanctuary, altar, tabernacle, Holy Mass, Eucharist, liturgical regulations 